\title{
Barley grain for ruminants: A global treasure or tragedy
}

\author{
Akbar Nikkhah*
}

\begin{abstract}
Barley grain (Hordeum vulgare L.) is characterized by a thick fibrous coat, a high level of ß-glucans and simply-arranged starch granules. World production of barley is about $30 \%$ of that of corn. In comparison with corn, barley has more protein, methionine, lysine, cysteine and tryptophan. For ruminants, barley is the third most readily degradable cereal behind oats and wheat. Due to its more rapid starch fermentation rate compared with corn, barley also provides a more synchronous release of energy and nitrogen, thereby improving microbial nutrient assimilation. As a result, feeding barley can reduce the need for feeding protected protein sources. However, this benefit is only realized if rumen acidity is maintained within an optimal range (e.g., > 5.8 to 6.0); below this range, microbial maintenance requirements and wastage increase. With a low pH, microbial endotoxines cause pro-inflammatory responses that can weaken immunity and shorten animal longevity. Thus, mismanagement in barley processing and feeding may make a tragedy from this treasure or pearl of cereal grains. Steam-rolling of barley may improve feed efficiency and post-rumen starch digestion. However, it is doubtful if such processing can improve milk production and feed intake. Due to the need to process barley less extensively than other cereals (as long as the pericarp is broken), consistent and global standards for feeding and processing barley could be feasibly established. In high-starch diets, barley feeding reduces the need for capacious small intestinal starch assimilation, subsequently reducing hindgut starch use and fecal nutrient loss. With its nutritional exclusivities underlined, barley use will be a factual art that can either matchlessly profit or harm rumen microbes, cattle production, farm economics and the environment.
\end{abstract}

Keywords: Barley, Cereal, Ruminant, Starch, Treasure

\section{Introduction}

Barley (Hordeum Spp.) is a cereal derived from the annual grass Hordeum Vulgare. This multipurpose grain deserves a top place in the farm for feeding livestock. It is irreplaceable by any other grain in beef and dairy diets for producing capacious rumen microbial yields [1]. This review delineates the nutritional and commercial status of barley and critically describes opportunities for its optimum use by rumen microbes, host ruminants, farmers and the environment.

\section{World production and distribution of barley}

In ranking of cereal crops conducted by the Food and Agriculture Organization of the United Nations [2], barley was ranked fourth in the world both in terms of

Correspondence: nikkhah@znu.ac.i

Department of Animal Sciences, Faculty of Agricultural Sciences, University of Zanjan, Zanjan 313-45195, Iran quantity produced (136 million tons) and in area of cultivation $\left(566,000 \mathrm{~km}^{2}\right)$. In 1994 to 1995 , world production of barley was estimated at 166 million metric tons (MMT) or about $30 \%$ of corn. In 2009 and 2010, world production of barley was 152 and 124 MMT, respectively (Table 1 ). The top barley producing countries are Germany, France, Ukraine and Russia [3].

During 2004, approximately $2000 \mathrm{kt}$ of barley and wheat were used by livestock in Australia representing $60 \%$ of all cereals fed [2]. Oats, sorghum, and triticale contributed only $20 \%, 10 \%$ and $10 \%$. About $40 \%$ of the barley was fed to feedlot cattle, 34\% to dairy cows, $20 \%$ to pigs, $6 \%$ to grazing ruminants, and $<1 \%$ to poultry. In Canada, barley is primary used in beef and dairy cattle diets although some finds its way into swine diets $[4,5]$. Barley makes up $40 \%$ of feed grain usage, equivalent to 7.3 MMT compared with 5.4 MMT for corn $[1,3,5]$. The U.S. (1.8 MMT), Japan (1.1 MMT) and Saudi Arabia (0.6 MMT) are major importers of Canadian barley [1-3]. 
Table 1 Top barley producers in the world (MMT)

\begin{tabular}{lrr}
\hline Country & $\mathbf{2 0 0 9}$ & $\mathbf{2 0 1 0}$ \\
\hline Germany & 12.3 & 10.4 \\
\hline France & 12.9 & 10.1 \\
\hline Ukraine & 11.8 & 8.5 \\
\hline Russia & 17.9 & 8.4 \\
\hline Spain & 7.4 & 8.2 \\
\hline Canada & 9.5 & 7.6 \\
\hline Australia & 7.9 & 7.3 \\
\hline Turkey & 7.3 & 7.2 \\
\hline United Kingdom & 6.8 & 5.3 \\
\hline United States & 5.0 & 3.9 \\
\hline World Total & 151.8 & 123.7 \\
\hline Source: Food and Agicultro
\end{tabular}

Source: Food and Agriculture Organization (2010).

\section{Nutritional value of barley}

It is important to understand that barley is not just barley. Many types of barley exist and it is important to know the type of barley being fed and the consequences this might have in terms of nutrient content. There may be considerable dissimilarities, particularly in starch content and rumen fermentation patterns, between some barley cultivars [6]. Knowledge of such differences can help farmers select and feed the most appropriate varieties that optimize production without compromising rumen and host animal health. Examples of barley types are two-rowed vs. six rowed as well as whole, hulless and pearled barley (Figure 1).

The nutrient composition of barley compared with other cereal grains is shown in Table 2. In comparison with corn, barley has more protein, methionine and cysteine, lysine, and tryptophan. This information highlights
Table 2 Nutrient composition of barley compared with other cereals $(\mathbf{g} / \mathbf{k g})$

\begin{tabular}{lcccccc}
\hline Nutrient (as fed) & \multicolumn{3}{c}{$\begin{array}{c}\text { Barley Hull-less Corn } \\
\text { barley }\end{array}$} & \multicolumn{3}{l}{ Wheat Sorghum Rye } \\
\hline Dry matter & 880 & 880 & 880 & 880 & 880 & 880 \\
\hline Crude protein (CP) & 115 & 132 & 88 & 135 & 110 & 121 \\
\hline $\begin{array}{l}\text { Undegradable CP, } \\
\text { g/kg CP }\end{array}$ & 280 & 350 & 500 & 250 & 550 & 200 \\
\hline $\begin{array}{l}\text { Neutral detergent } \\
\text { fibre }\end{array}$ & 181 & 120 & 108 & 118 & 161 & 180 \\
\hline Acid detergent fibre & 60 & 20 & 30 & 40 & 90 & 100 \\
\hline Starch & 570 & 650 & 720 & 770 & 720 & 620 \\
\hline Fat & 19 & 20 & 38 & 22 & 29 & 15 \\
\hline Ash & 23 & 19 & 14 & 17 & 18 & 19 \\
\hline Lysine & 4.3 & 5.0 & 2.1 & 3.5 & 2.7 & 4.0 \\
\hline Methionine + Cysteine & 4.2 & 5.6 & 3.0 & 5.1 & 3.0 & 3.6 \\
\hline Tryptophan & 1.8 & 1.5 & 0.9 & 1.5 & 0.9 & 1.4 \\
\hline NE $E_{L}$ Mcal/kg & 1.71 & 1.75 & 1.78 & 1.82 & 1.62 & 1.71 \\
\hline Data from Hun
\end{tabular}

Data from Huntington (1997), NRC (2001). Net energy for lactation ( $\mathrm{NE}_{\mathrm{L}}$ ) of barley varies (e.g., 1.5-1.9 Mcal/kg) depending on dietary inclusion rate and processing method.

the potential contribution of barley to meeting the protein requirements of high-producing ruminants [4,7]. In addition, in comparison with other cereal grains, barley contains the highest levels of neutral and acid detergent fiber and the lowest levels of starch and fat.

As shown in Table 3, barley is richest in potassium and vitamin-A among the common cereals. Barley grain contains five times more calcium than oats. With twice as much copper and molybdenum and $>$ twice as much manganese, barley is superior to corn. However, barley is poorer in zinc compared with corn. The nutrients
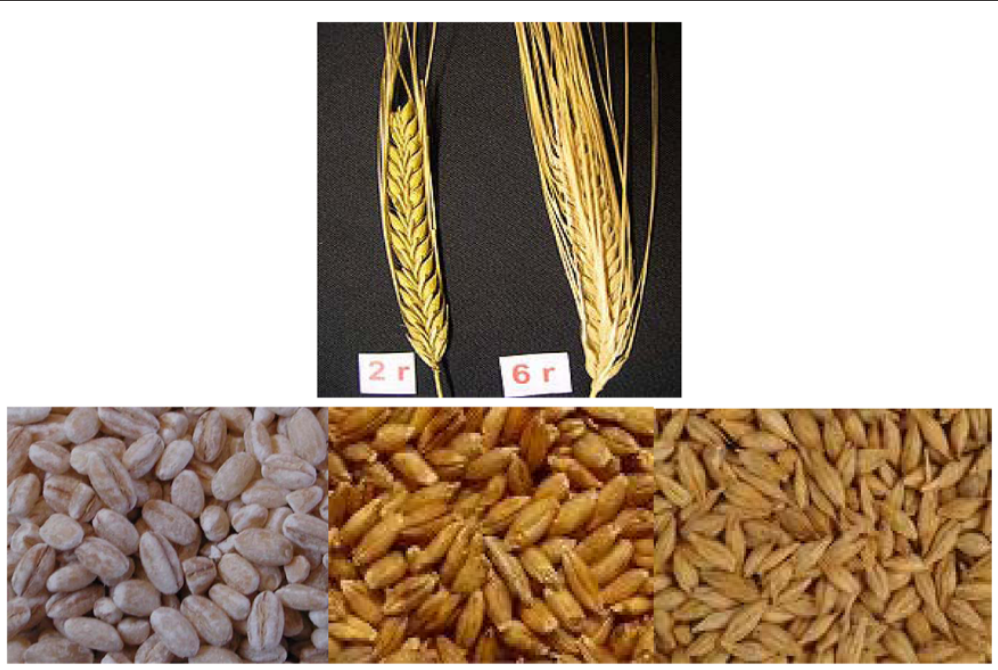

Figure 1 Top: Varieties of two-rowed and six-rowed barley. Bottom: Whole barley (right), naked or hull-less barley (middle) and pearled barley (left). 
Table 3 Mineral and vitamin content of the major cereal grains (g/kg of DM)

\begin{tabular}{lccccc}
\hline Nutrient & Barley & Corn & Wheat & Oats & Sorghum \\
\hline Calcium & 0.5 & 0.3 & 0.5 & 0.1 & 0.4 \\
\hline Phosphorous & 3.5 & 3.2 & 4.4 & 4.1 & 3.4 \\
\hline Potassium & 5.7 & 4.4 & 4.0 & 5.1 & 4.4 \\
\hline Magnesium & 1.2 & 1.2 & 1.3 & 1.6 & 1.7 \\
\hline Sodium & 0.1 & 0.1 & 0.1 & 0.2 & 0.1 \\
\hline Sulfur & 1.5 & 1.1 & 1.4 & 2.1 & 1.4 \\
\hline Copper, ppm & 5.3 & 2.5 & 6.5 & 8.6 & 4.7 \\
\hline Iron, ppm & 59.5 & 54.5 & 45.1 & 94.1 & 80.8 \\
\hline Manganese, ppm & 18.3 & 7.9 & 36.6 & 40.3 & 15.4 \\
\hline Selenium, ppm & - & 0.14 & 0.05 & 0.24 & 0.46 \\
\hline Zinc, ppm & 13.0 & 24.2 & 38.1 & 40.8 & 1.0 \\
\hline Cobalt, ppm & 0.35 & - & - & 0.06 & - \\
\hline Molybdenum, ppm & 1.16 & 0.60 & 0.12 & 1.70 & - \\
\hline Vit A, 1000 IU/kg & 3.8 & 1.0 & 0.0 & 0.2 & 0.05 \\
\hline Vit E, 1000 IU/kg & 26.2 & 25.0 & 14.4 & 15.0 & 12.0 \\
\hline NRC (1996, 2001) & & & & & \\
\hline
\end{tabular}

NRC (1996, 2001).

lacking in barley include vitamin $\mathrm{C}$ and vitamin $\mathrm{B}_{12}$. Noteworthy, few differences exist in nutrient composition between two-rowed and six-rowed barleys (Table 4).

Large differences exist among individual barley samples in terms of available energy and animal performance [8,9]. In an Australian assessment [10], pigs obtained greater energy from barley than other animals (Figure 2), whereas cattle utilized the energy in barley the least [10]. Correlations for the utilizable energy of barley between broilers and other animals were 0.77 for layers, 0.56 for pigs and 0.09 for cattle. The correlation between pigs and cattle was 0.71 . These coefficients indicate significant differences among livestock in the digestive capacity of individual barleys. Some samples are more digestible by ruminants than pigs or poultry and indeed vice versa. Figure 2 shows that sample 1 was poorly digested by all animals. The useable energy of

Table 4 Average density and nutrient composition of North Dakota two-rowed and six-rowed barley varieties

\begin{tabular}{lcc}
\hline Nutrient & Two-row & Six-row \\
\hline Test weight, kg/bushel & 48.4 & 46.2 \\
\hline Dry matter, g/kg & 908 & 906 \\
\hline Neutral detergent fiber, g/kg & 200 & 214 \\
\hline Acid detergent fiber, g/kg & 62 & 66 \\
\hline Crude protein, g/kg & 129 & 124 \\
\hline Calcium, g/kg & 0.5 & 0.5 \\
\hline Phosphorous, g/kg & 3.6 & 3.7 \\
\hline Magnesium, g/kg & 1.4 & 1.4 \\
\hline Potassium, g/kg & 5.4 & 5.4 \\
\hline Data from regional information during 1991 & $1997[5,6]$ &
\end{tabular}

Data from regional information during 1991-1997 [5,6]. sample 4 was low for cattle and pigs, but medium for poultry. However, sample 5 provided low energy to cattle, high energy to poultry, and medium energy to pigs. The available energy of sample 17 was higher for cattle, lower for pigs, and much lower for poultry, whilst sample 18 generated more energy for cattle and pigs, low energy for broilers, and medium energy for layers.

Such versatilities in the energy value of barley originate from differential digestive systems and assimilative capacity between livestock species as well as disparities in chemical and physical properties of different barley samples [10]. Accordingly, assortment measures for breeding barley most suitable for different livestock can be developed. Barleys with low hull and fiber content, fragile cell walls, and thus low soluble arabinoxylans and ß-glucans and rapidly accessible starches are optimal for pigs. For poultry, samples with lower non-starch polysaccharides and thus lower viscosity, and low condensed tannins are greatly needed. On the other hand, for ruminants, cultivars with higher fiber and soluble arabinoxylans specifically with harder kernels to produce slower rumen starch degradation rates (i.e., low acidosis index) are preferred.

Near Infrared Reflectance Spectroscopy calibrations have been developed for premium grains in livestock programs to predict the available energy intakes for poultry, pigs, with other grain properties such as acidosis index. These calibrations help to monitor grains within barley breeding programs and to assign the most suitable grain samples to the appropriate livestock production system.

\section{Anti-nutritional factors in barley}

Anti-nutritional factors occur in barley. A mycotoxin that grows on barley plants and barley is deoxynivalenol also known as vomitoxin. It is generated by a fusarium that grows on moist barley and wheat under humid conditions during the early heading stages. Nonetheless, evidence suggests no effects of vomitoxin on feed intake or milk production of cows.

\section{Feeding ruminants barley together with other grains and enzymes}

Mixtures of grains offer advantages in beef and dairy cattle feeding [11]. This is due to their greater extent and rate of rumen starch fermentation $[12,13]$. Such blends can alleviate the rumen acidosis which usually occurs by feeding highly fermentable grains e.g., barley (Figure 3). Blending barley and corn, before processing/flaking, did not compromise feedlot cattle performance [14]. In grazing Jersey cows, replacing $50 \%$ of corn with barley in concentrates increased milk production, suggesting positive associative effects of corn and barley [11]. More data on feeding combinations of different cereals are 


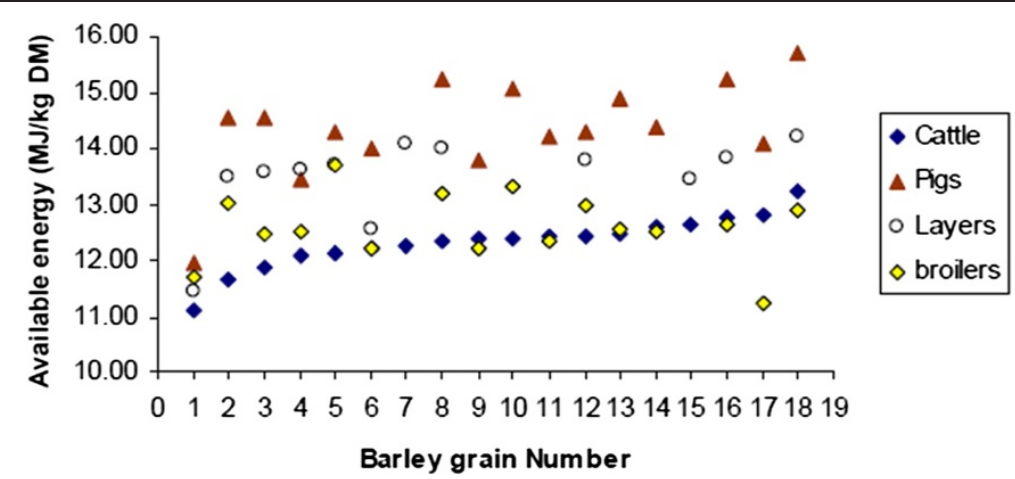

Figure 2 Available energy for 18 samples of barley fed to livestock ad libitum (Adopted from [10]).

needed before clear-cut recommendations can be offered to the world ruminant industries. Adding xylanase-based fibrolytic enzymes to high concentrate (e.g., $950 \mathrm{~g}$ barley/kg of diet dry matter) diets improved feed efficiency without effects on daily gain and feed intake [15].

\section{Processing barley for beef and dairy cattle}

Grain processing can affect the rate, extent and site of protein, fiber and starch digestion [16] (Figure 3, Table 5).

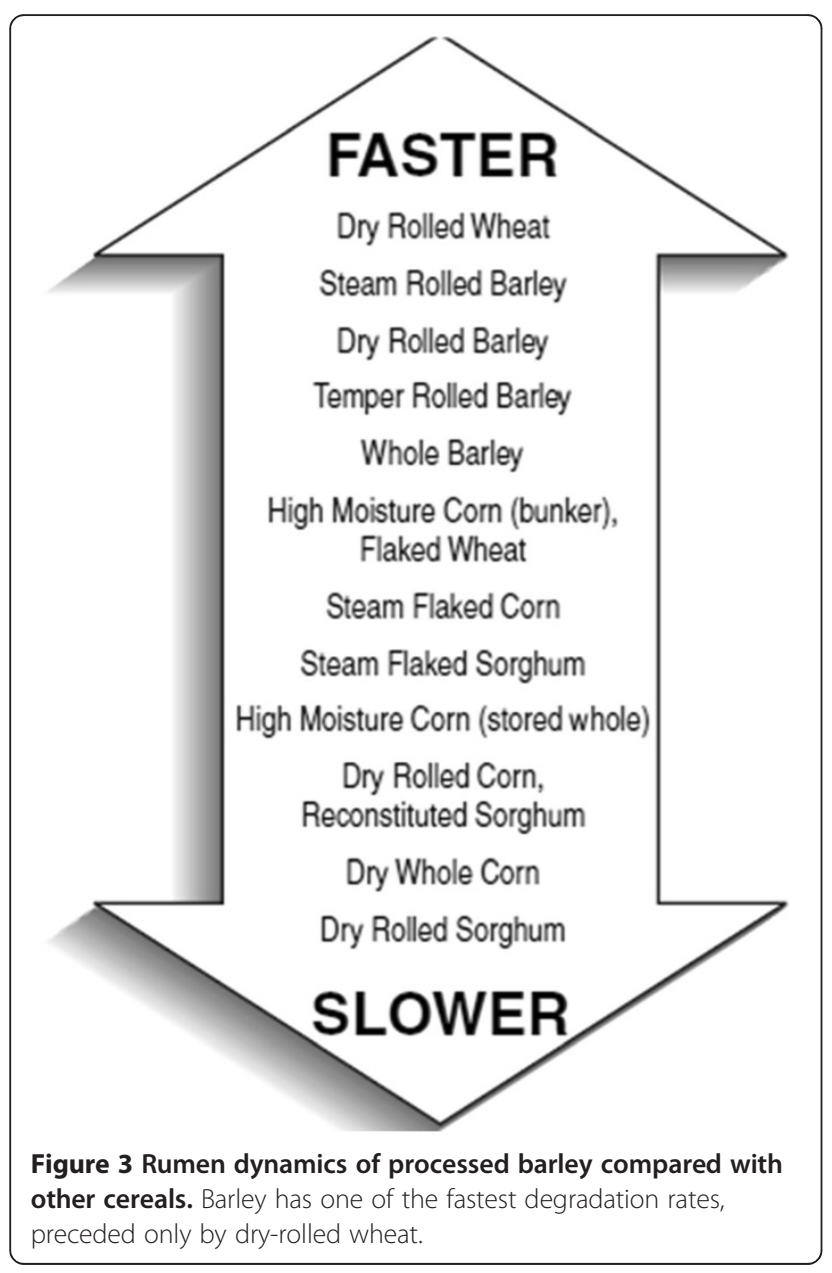

Due to their inability to properly chew and break the husky kernels, whole barley cannot be fed to large ruminants [17]. As a result, barley is commonly rolled, tempered, steam-flaked, ground, roasted or pelleted [1]. While grinding is the most common and preferred technique to process barley for dairy cows in Iran $[1,18]$, tempering, dry-rolling and steam-rolling are common in North America, Australia and Western Europe $[19,20]$. Tempering involves adding water for 24 hours prior to rolling to increase the moisture content of the barley up to 180 to $200 \mathrm{~g} / \mathrm{kg}$. Tempering results in fewer fine particles compared with dry rolling [21], which reduces the risk of rumen acidosis. Consequently, starch fermentation rate can decrease, thereby reducing the risks associated with a sharply-reduced rumen $\mathrm{pH}$. As such, tempered barley, compared with dry rolled barley, improved milk yield by $5 \%$, feed efficiency by $10 \%$, and apparent digestibility of dry matter, neutral detergent

Table 5 In vivo ruminal starch and protein degradation (\% of intake) of differently proceed barley compared with wheat, corn and sorghum ${ }^{1}$

\begin{tabular}{llll}
\hline Processed grain & $\begin{array}{l}\text { Rumen } \\
\text { degradation, \% }\end{array}$ & $\begin{array}{l}\text { Post-rumen } \\
\text { digestion, \% }\end{array}$ & $\begin{array}{l}\text { Total tract } \\
\text { digestion, \% }\end{array}$ \\
\hline Steam-rolled barley & 84.6 & 13.6 & 98.2 \\
\hline Dry-rolled barley & 80.7 & 13.7 & 94.3 \\
\hline Ground barley & 88.0 & 10.5 & 98.5 \\
\hline Steam-rolled wheat & 88.1 & 10.0 & 98.6 \\
\hline Dry-rolled wheat & 88.3 & 9.9 & 98.2 \\
\hline Ground wheat & 90.0 & 8.9 & 99.9 \\
\hline Steam-flaked corn & 84.8 & 14.1 & 98.9 \\
\hline Dry-rolled corn & $76.2(35)^{2}$ & 16.2 & 92.4 \\
\hline Ground corn & 49.5 & 44.0 & 93.5 \\
\hline Steam-flaked sorghum & 78.4 & 19.6 & 98.0 \\
\hline Dry-rolled sorghum & 59.8 & 26.1 & 87.2 \\
\hline Ground sorghum & 70 & 15.4 & 91.0 \\
\hline
\end{tabular}

'Data obtained from Nikkhah et al. (2004), Nikkhah and Ghorbani (2003), Huntington (1997), Herrera-Saldana et al. (1990) (51-55).

${ }^{2}$ The value within parenthesis shows dramatic variation. 
fiber, acid detergent fiber, crude protein and starch by $6 \%, 15 \%, 12 \%, 10 \%$ and $4 \%$, respectively [22].

Aggressive and high-pressure exposure to heat may reduce the degradation rate of barley [23]. This reduction is important in vivo, especially directly after feeding when rumen fermentation peaks. Such moderated barley degradation rates can improve feed efficiency likely via increased rumen $\mathrm{pH}$ and attenuated rumen acidosis during fermentation peaks as well as increased small intestinal escape or partially-digested starch assimilation [24]. Likewise, flame roasting of barley reduced dry matter and crude protein rumen degradation despite no effects on total tract digestibilities [25]. Feeding roasted barley instead of rolled barley twice a day improved milk yield by $3 \mathrm{~kg}$ [25]. Nonetheless, in vivo actual data (versus in vitro and in situ estimates) on post-rumen and especially small intestinal digestion of protein and starch from differently processed barley in high-producing ruminants are greatly limited.

Feeding yearling steers steam-rolled barley instead of high moisture corn in diets with $650 \mathrm{~g}$ grain, $160 \mathrm{~g}$ forage, $50 \mathrm{~g}$ supplement and $140 \mathrm{~g}$ potato residues per $\mathrm{kg}$ of diet did not affect weight gain, but decreased dry matter intake cubically with increased levels of barley [26]. In finishing diets with $840 \mathrm{~g}$ grain, $120 \mathrm{~g}$ alfalfa haylage and $40 \mathrm{~g}$ supplement per $\mathrm{kg}$ of diet, dry-rolled barley and corn affected cattle performance, carcass properties, and the incidence of digestive disorders similarly [27]. Replacing dry-rolled corn with tempered barley in $60 \mathrm{~g} / \mathrm{kg}$ forage finishing diets resulted in no differences in intake and weight gain in response to different ratios of the two grains [28]. However, steers fed the blend of grains had greater carcass weights, yield grades, and 12th rib fat than did steers fed single grains. These

Table 6 Production, digestion, and metabolism of mid-lactation Holstein cows fed ground versus steam-rolled barley-based total mixed rations containing corn silage and alfalfa hay

\begin{tabular}{llllc}
\hline Level of barley & \multicolumn{2}{c}{$\mathbf{2 6} \%$ barley } & \multicolumn{2}{c}{ 32.5 \% barley } \\
\hline Processing method & Ground & Rolled & Ground & Rolled \\
\hline Dietary starch, \% & 18.0 & 18.0 & 26.8 & 26.8 \\
\hline Dietary neutral detergent fiber, \% & 38.0 & 38.0 & 34.3 & 34.3 \\
\hline Dietary acid detergent fiber, \% & 24.1 & 24.1 & 19.0 & 19.0 \\
\hline Dietary crude protein, \% & 16.1 & 16.1 & 18.9 & 18.9 \\
\hline Dry matter intake, kg/d & 23.5 & 23.9 & 24.8 & 24.4 \\
\hline Fat corrected milk, kg/d & 27.8 & 28.6 & 36.1 & 37.7 \\
\hline Milk fat yield, kg/d & 1.07 & 1.07 & 1.29 & 1.37 \\
\hline Milk protein yield, kg/d & 0.83 & 0.85 & 1.07 & 1.10 \\
\hline Rumen pH & 6.7 & 6.6 & 5.7 & 5.7 \\
\hline Chewing time, min/d & - & - & 820 & 803 \\
\hline Total tract dry matter digestibility $\%$ & 69.0 & 69.0 & - & - \\
\hline
\end{tabular}

Nikkhah (2011); Sadri et al. (2007); Soltani et al. (2009) $(18,37,39)$. data suggest more efficient uses of barley when fed in combination with corn rather than when fed alone.

Steam-rolled barley was similar to steam-rolled corn in affecting milk yield of lactating cows [29]. This was also the case in complete mixed cubed diets [30], with dry-rolled barley versus ground corn [30,31], or with both grains in the ground form [32,33]. Dry-rolled barley successfully replaced the high-energy dry-rolled grain sorghum with respect to milk yield, and tended to improve feed efficiency [34]. Dry rolled barley and ground corn with and without bovine somatotropin (bST) similarly affected bST response, milk production, somatic cell count, and cow weight [35]. However, slight declines in milk production and feed intake were reported for barley versus corn fed cattle [36]. This could be due to overly reduced rumen $\mathrm{pH}$ and depressed fiber digestion and the supply of milk precursors under suboptimal circumstances. With prudent and more moderate uses in dairy diets, ground barley has proved superior to ground broomcorn and as competent as steam-flaked broomcorn in maintaining feed intake and milk production [37] (Table 6). These findings emphasize the science-based experience that dietary inclusion rate

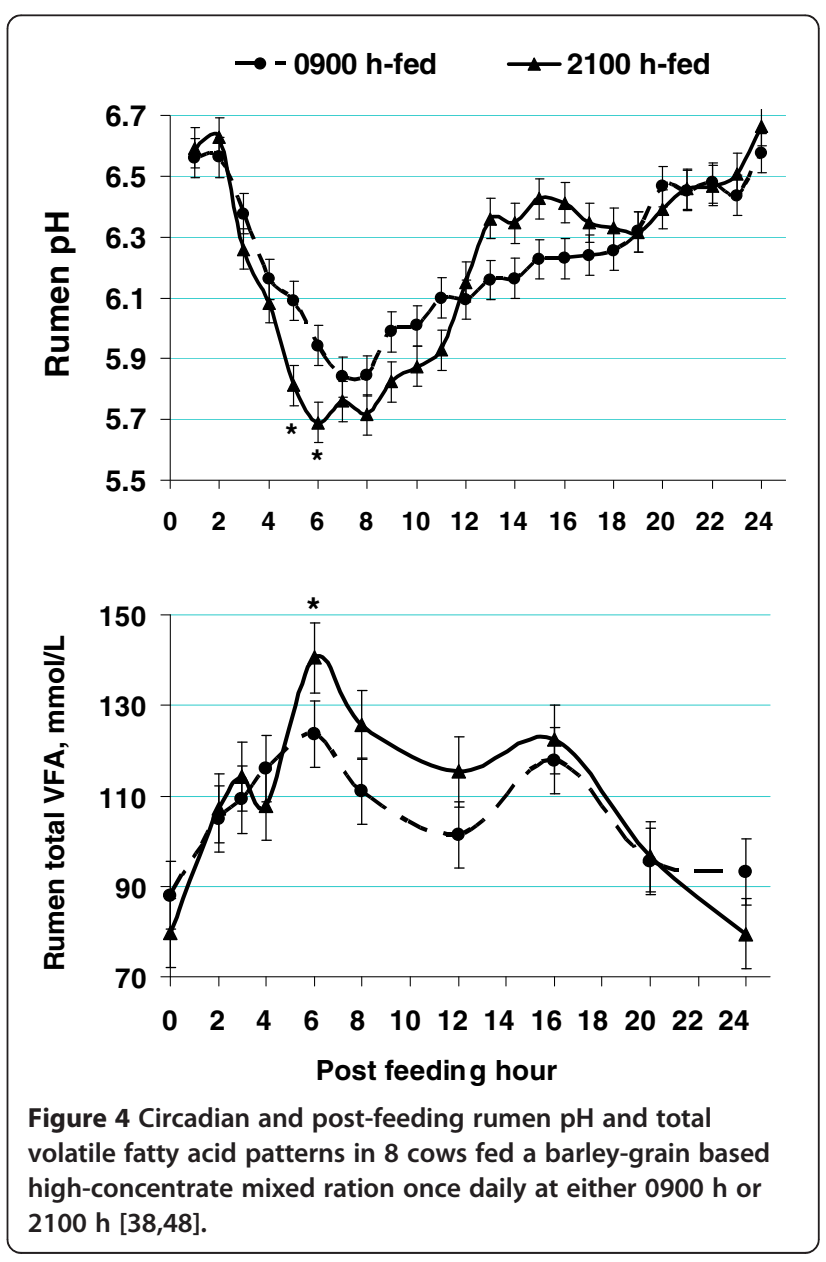


of barley requires more deserving thoughts for optimal rumen function and ruminant production and welfare $[1,18,38]$.

Based on NRC recommendations [7], dairy diets should contain $25 \%$ to $28 \%$ neutral detergent fiber, $75 \%$ of which must be supplied by forages. This is needed for adequate chewing and healthy rumen function, and to prevent milk fat depression and laminitis [24]. Barley-based diets usually supply greater amounts of neutral detergent fiber than corn-based diets. However, due to the inadequate effectiveness of the neutral detergent fiber of barley in stimulating chewing and ensalivation as well as the greater degradation rate of barley than corn, barley-fed cows require greater effective forage fiber than corn fed cows [29]. Normally, rumen cellulolytic bacteria numbers are sufficiently maintained under $\mathrm{pH}>6.0$. Thus, so long as barley feeding does not lower rumen $\mathrm{pH}$ below 5.8 to 6.0, it can replace the more expensive corn in dairy diets.

Recent findings compellingly suggest that finely ground barley is not inferior to the more expensive steam-rolled barley if dietary barley inclusion rate is kept sensibly moderate at $\leq 300 \mathrm{~g} / \mathrm{kg}$ of diet dry matter [39,40] (Table 6). Even at $350 \mathrm{~g} / \mathrm{kg}$ barley, except for a modest improvement in feed efficiency, milk production and dry matter intake were similar between ground and steam-rolled barley fed cows [18].

Overfeeding barley is an easy shortcut to rumen acidosis and triggered pro-inflammatory responses of depressed immune function [41,42]. Feeding $>35 \%$ barley $/ \mathrm{kg}$ of dietary dry matter is under no circumstances recommended. Thus, whilst barley is a matchless source of rapidly released energy for efficient rumen microbial mass and volatile fatty acid yields, its dietary use must be an art
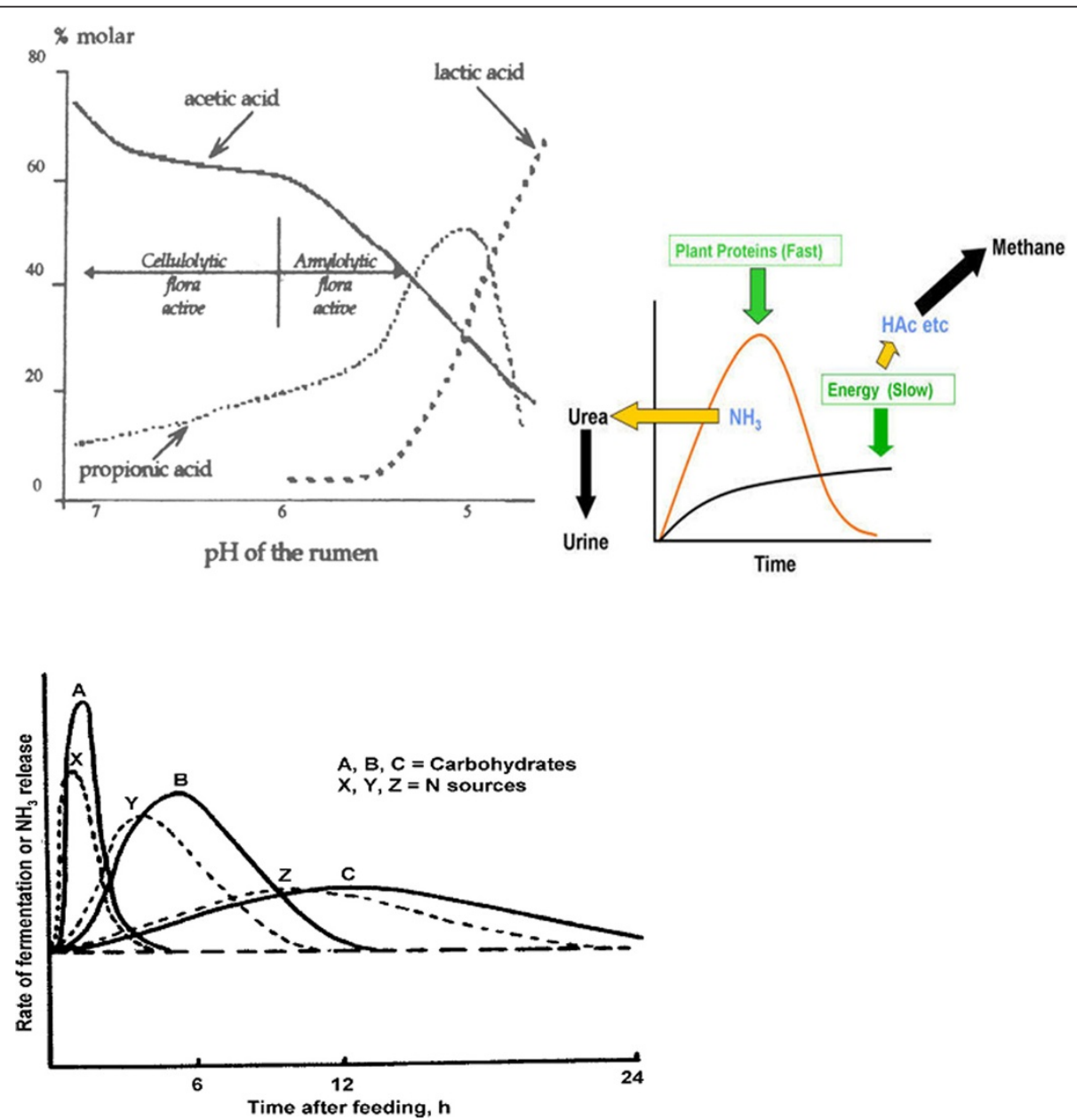

Figure 5 Top right: The slower rate of dietary energy vs. protein fermentation. Top left: Relationships among rumen $\mathrm{pH}$, differential volatile fatty acids and lactate concentrations and prevalence of cellulolyric versus amylolytic bacteria. Bottom: Rumen release of rapidly ( $\mathrm{A}$, X), moderately $(B, Y)$ and slowly $(C, Z)$ degradable carbohydrates and nitrogen fractions over time for microbial mass yield. The AX and BY curves would represent post-feeding fermentation patterns of barley and corn respectively $(1,5,12,54,55)$. Increased asynchrony of carbohydrate and protein release and prolonged rumen acidosis can make a tragedy from the treasure barley. 
to allow such benefits to become a reality in optimizing production and health concomitantly [1]. As much as being the pearl of cereals, indispensable for persistent peaks in beef and dairy production, improper feeding of no other grain can be as much economically and environmentally devastating as barley $[43,44]$.

\section{Rumen physiology and health aspects of barley feeding} Cows fed overly high amounts of rapidly fermentable starches such as barley are very likely to experience periods of subacute rumen acidosis which can increase the incidence of laminitis [45,46]. High levels of ground cereals are also thought to predispose cattle to lameness, resulting from acidosis. These challenges occur mostly because barley, regardless of processing technique, has a much greater extent of rumen fermentation and higher fermentation rate than other processed grains, preceded only by dry-rolled wheat grain (Table 5, Figure 3). Recent evidence suggests that with optimal barley inclusion rate in dairy rations, ground barley can be as palatable and effectively utilized as steam-processed barley $[1,18]$ (Table 6). Thus, pragmatically, it is not grinding that is problematic, but it is rather the very high dietary levels of barley that introduces serious challenges to the rumen and cow metabolism and immunity $[1,41]$.

As illustrated in Figures 4 and 5, rumen fermentation possesses circadian patterns in $\mathrm{pH}$ and volatile fatty acid concentrations that depend on feed delivery and feeding behavior $[47,48]$. As such, most dramatic fluctuations occur around feeding and shortly after when the rumen receives a considerable amount of substrate.

A common challenge in optimizing rumen fermentation is the asynchrony in fermentation rate and patterns of protein and energy [1,49-55] (Figure 5). Proteins and carbohydrates have rapidly, moderately, and slowly degradable fractions and each of these nourish specific microbial populations. In addition, proteins are usually degraded more rapidly than carbohydrates upon feeding (Figure 5). This means that the maximum rumen energetic potential is reached when proteins have already gone through their maximum degradation. Thus, loss of nitrogen and energy as ammonia, methane and carbon dioxide would result.

Feeding barley-based diets is expected to alter fermentation patterns (Figure 5), such that an earlier energy fermentation peak would occur to reduce the asynchrony and improve substrate incorporation into the microbial mass. Such shifted fermentation patterns can optimize energy efficiency and milk biosynthesis, and reduce methane, ammonia and urinary nitrogen outputs [18]. However, due to its highly degradable nature in the rumen, regardless of processing method, barley must not be overfed (e.g., < 35 \% of diet dry matter) (Tables 5,6) $[1,18,39,40]$. Under rapid fermentation of the overfed barley starch, rumen $\mathrm{pH}$ will fall and persist below 5.8 where rumen acidosis will govern. The incidence of rumen acidosis in large herds can have detrimental consequences on feed efficiency and economical sustainability [50]. Dramatic and persistent acidic environments will coexist with, and further result in, increased lactic acid production. Lactic acid has a lower pKa than the volatile fatty acids (3.8 vs. 4.8). At lower $\mathrm{pH}$, greater proportions of lactic acid will occur in undissociated forms $[43,50]$, the accumulation of which plus that of volatile fatty acids will progressively interfere with efficient acid absorption, thus prolonging rumen acidosis and exacerbating the problem. Under such acidotic conditions,

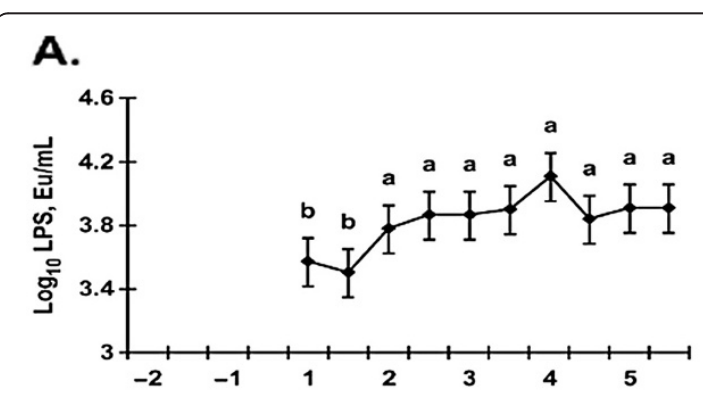

B.

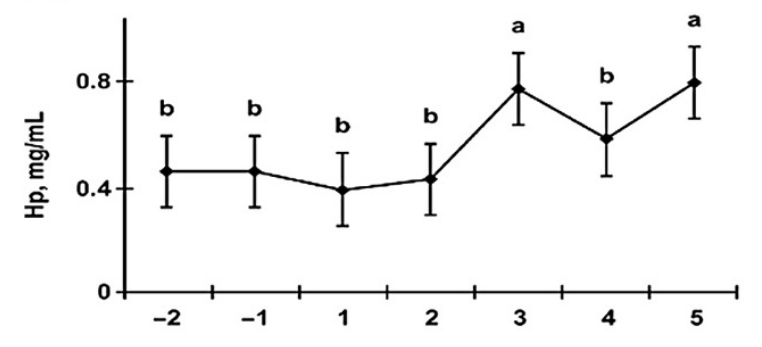

C.

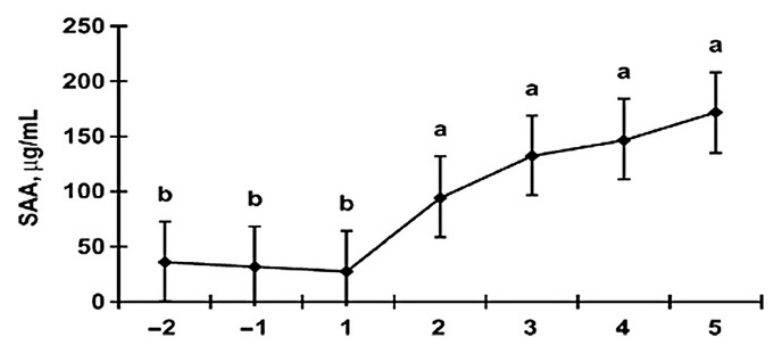

Figure 6 Ruminal lipopolysaccharides (LPS, $\log 10$ endotoxin units/mL; Figure $A$ ), haptoglobin (Hp; Figure $B)$, and serum amyloid-A (SAA; Figure $C$ ) in steers fed chopped alfalfa hay only (days -2 and -1 ) and barley-wheat based pelleted concentrate (days 1 to 5). Diet $1=4 \mathrm{~kg}$ of barley-wheat pellets and $6 \mathrm{~kg}$ of chopped alfalfa hay offered daily; Diet $2=5 \mathrm{~kg}$ of barley-wheat pellets and $5 \mathrm{~kg}$ of chopped alfalfa hay offered daily; Diet $3=6 \mathrm{~kg}$ of barley-wheat pellets and $4 \mathrm{~kg}$ of chopped alfalfa hay offered daily. Different letters declare statistical significance. Daily duration of time at which pH was below 5.6 (as an indicator of subacute rumen acidosis) was 42, 117, and $134 \mathrm{~min} / \mathrm{d}$ for Diets 1, 2, and 3, respectively [42]. 
microbial mass yield will drop noticeably and bacteria will lyse, which will cause endotoxin release and trigger systemic pro-inflammatory responses [51]. This is evident in elevated circulating levels of haptoglobin and serum amyloid-A indicative of rumen acidosis in barley fed cattle [42] (Figure 6). Therefore, rumen acidosis can weaken cattle immunity and depress productivity and thereby threaten farm economics and sustainability.

\section{Conclusions and implications}

Barley grain is known for its thick fibrous coat, high content of $ß$-glucans and less complicated starch granules. With about 150 MMT of annual yield, world production of barley is about $30 \%$ of corn. Universally, barley is typically cheaper and less demanded by nonruminants and humans than corn and wheat. Besides greater protein, barley is richer in methionine, lysine, cysteine, and tryptophan than corn. Barley is considered highly degradable in the rumen. Owing to its more rapid and extensive rumen starch and nitrogen fermentation compared with ground corn, barley may provide more synchronous energy and nitrogen release, which can improve microbial and host nutrient assimilation. Proper barley feeding management may reduce expensive undegradable protein requirements. Conversely, with improper dietary inclusion rate and processing, no other grain can as easily be a shortcut to prolonged rumen acidosis, microbial endotoxin release, pro-inflammatory responses, and suppressed immune function as barley. Due to the need to process barley less extensively than corn, sorghum or wheat (as long as the pericarp is broken), establishing consistent and global standards for feeding and processing could be more feasible for barley than other grains. Feeding barley to modern ruminants must be a factual art that will matchlessly profit or otherwise dramatically impair rumen microbes, host health and production, farm economics, and the environment. Optimal dietary inclusion rates of barley are where global tragedies could be well avoided by a treasure.

\section{Abbreviations}

ADF: Acid Detergent Fiber; BG: Barley Grain; CG: Corn grain; CP: Crude Protein; DM: Dry Matter; NDF: Neutral Detergent Fiber; SARA: Subacute Rumen Acidosis; TMR: Total Mixed Ration; VFA: Volatile Fatty Acids.

\section{Competing interests}

The author declares no competing interests.

\section{Acknowledgements}

The Ministry of Science, Research and Technology, and University of Zanjan, Iran are gratefully acknowledged for supporting the author's programs of optimizing science education worldwide.

\section{Author details}

Doctor Akbar Nikkhah, PH.D., is Highly Distinguished Professor of Science and Ruminant Nutrition, Highly Distinguished Mentor of Science Education and Dissemination, and Highly Distinguished Science Composer/Speaker currently in the Department of Animal Sciences, University of Zanjan in Iran; and Highly Distinguished Elite-Generating Scientist of the National Elite Foundation in Iran. He is also Highly Distinguished Global Peace Leader.

Received: 8 January 2012 Accepted: 9 July 2012

Published: 9 July 2012

\section{References}

1. Nikkhah A: Barley grain for rumen and ruminants: Over-modernized uses of an inimitable fuel. In Barley: Production, Cultivation and Uses. Edited by Elfson SB. NY, USA: Nova Science Publishers, Inc; 2011:247-258.

2. FAOSTAT: Food and Agriculture Organization of the United Nations. 2010. http://www.faostat.fao.org/.

3. United States Department of Agriculture: World Agricultural Production Foreign Agricultural Service. Circular Series WAP06-12. 2010. http://www.fas. usda.gov/wap/current.

4. National Research Council: Nutrient Requirements of Beef Cattle. 7th edition. Washington, D.C: National Academy Press; 1996.

5. Nikkhah A: Postmodern management of starchy grains for ruminants: A barley grain perspective. Rus Agric Sci 2012, 38:14-21.

6. Silveira C, Oba M, Beauchemin KA, Helm J: Effect of grains differing in expected ruminal fermentability on the productivity of lactating dairy cows. J Dairy Sci 2007, 90:2852-2859.

7. National Research Council: Nutrient Requirements of Dairy Cattle. 7th edition. Washington, D.C: National Academy Press; 2001.

8. Boss DL, Bowman JG: Barley varieties for finishing steers: I. Feedlot performance, in vivo diet digestion, and carcass characteristics. J Anim Sci 1996, 74:1967-1972.

9. Van Barneveld RJ: Chemical and physical characteristics of grains related to variability in energy and amino acid availability in pigs: A review. Aust J Agric Res 1999, 50:667-687.

10. Black JL, Tredrea AM, Nielsen SG, Flinn PC, Kaiser AG, van Barneveld RJ: Feed uses for barley. Proceedings of the $12^{\text {th }}$ Australian Barley Technical Symposium. Tasmania: Hobart; 2005.

11. Lehmann M, Meeske R: Substituting maize grain with barley grain in concentrates fed to Jersey cows grazing kikuyu-ryegrass pasture. South Afr J Anim Sci 2006, 36(3):175-180.

12. Bock BJ, Brandt RT, Harmon DL, Anderson SJ, Elliot JK, Avery TB: Mixtures of wheat and high-moisture corn in finishing diets: Feedlot performance and in situ rate of starch digestion in steers. J Anim Sci 1991, 69:2703-2710.

13. Kreikemeier R, Stock A, Brink DR, Britton RA: Feeding combinations of dry corn and wheat to finishing lambs and cattle. J Anim Sci 1987, 65:1647-1654

14. Zinn RA, Barajas R: Influence of flake density on the comparative feeding value of a barley-corn blend for feedlot cattle. J Anim Sci 1997, 75:904-909.

15. Beauchemin KA, Jones SDM, Rode LM, Sewalt VJH: Effects of fibrolytic enzymes in corn or barley diets on performance and carcass characteristics of feedlot cattle. Can J Anim Sci 1997, 77:645-653.

16. Mathison GW: Effects of processing on the utilization of grain by cattle. Anim Feed Sci Technol 1996, 58:113-125

17. Valentine SC, Wickes RB: The production and composition of milk from dairy cows fed hay supplemented with whole, rolled or alkali treated barley grain. Proc Aust Soc Anim Prod 1980, 13:397-400.

18. Nikkhah A: Optimizing barley grain use by dairy cows: $A$ betterment of current perceptions. In Progress in Food Science and Technology. Volume 1. Edited by Greco AJ. NY, USA: Nova Science Publishers, Inc; 2011:165-178.

19. Yang WZ, Beauchemin KA, Rode LM: Effects of barley grain processing on extent of digestion and milk production of lactating cows. J Dairy Sci 2000, 83:554-568.

20. Zinn RA: Influence of processing on the comparative feeding value of barley for feedlot cattle. J AnimSci 1993, 71:3-10.

21. Anderson V, Schroeder JW: Feeding barley to dairy cattle. Fargo, North Dakota: North Dakota State University Extension Service; 2010. www.ag. ndsu.edu.

22. Christen SD, Hill TM, Williams MS: Effects of tempered barley on milk yield, intake, and digestion kinetics of lactating Holstein cows. J Dairy Sci 1996, 79:1394-1399.

23. Ljøkjel K, Harstad OM, Prestløkken E, Skrede A: In situ digestibility of starch in barley grain (Hordeumvulgare) and peas (Pisumsativum L.) in dairy cows: Influence of heat treatment and glucose addition. Anim Feed Sci Technol 2003, 107:105-116. 
24. Owens FN, Secrist DS, Hill WJ, Gill DR: The effect of grain source and grain processing on performance of feedlot cattle: A review. J Anim Sci 1997, 75:868-879.

25. McNiven MA, Hamilton RMG, Robinson PH, DeLeeuiwe JW: Effect of flame roasting on the nutritional quality of common cereal grains for ruminants and non-ruminants. Anim Feed Sci Technol 1994, 47:31-40.

26. Duncan RW, Males JR, Nelson ML, Martin EL: Corn and barley mixtures in finishing steer diets containing potato process residue. J Prod Agric 1991, 4:426-432.

27. Gray DG, Stallknecht GF: Barley versus corn in finishing diets for beef calves. Proc West Sec Am Soc Anim Sci 1988, 39:322-323.

28. Combs JJ, Hinman DD: Use of high moisture ear corn, corn and barley in beef cattle finish rations. Proc West Sec Am Soc Anim Sci 1988, 39:402-405.

29. Beauchemin KA, Rode LM: Minimum versus optimum concentrations of fiber in dairy cow diets based on barley silage and concentrates of barley or corn. J Dairy Sci 1997, 80:1629-1639.

30. DePeters EJ, Taylor SJ: Effects of feeding corn or barley on composition of milk and diet digestibility. J Dairy Sci 1985, 68:2027-2032.

31. Grings EE, Roffler RE, Deitelhoff DP: Evaluation of corn and barley as energy sources for cows in early lactation fed alfalfa-based diets. J Dairy Sci 1992, 75:193.

32. Park CS: Feeding barley to dairy cattle. North Dakota Farm Research. 1988 , 46:18-19.

33. Rode LM, Satter LD: Effect of amount and length of alfalfa hay in diets containing barley or corn on site of digestion and rumen microbial protein synthesis in dairy cows. Can J Anim Sci 1988, 68:445-454

34. Santos FAP, Huber JT, Theurer CB, Swingle RS, Wu Z, Simas JM, Chen LH, Chan SC, Santos J, DePeters EJ: Comparison of barley and sorghum grain processed at different densities for lactating dairy cows. J Dairy Sci 1997 80:2098-2103.

35. Eisenbeisz WA, Schingoethe DJ, Casper DP, Shaver RD, Cleale RM: Lactational evaluation of recombinant bovine somatotropin with corn and barley diets. J Dairy Sci 1990, 73:1269-1279.

36. Casper DP, Schingoethe DJ: Lactational response of dairy cows to diets varying in ruminal solubilities of carbohydrates and crude protein. J Dairy Sci 1989, 72:928-941.

37. Nikkhah A, Alikhani M, Amanlou H: Effects of feeding ground or steam-flaked broom sorghum and ground barley on performance of dairy cows in midlactation. J Dairy Sci 2004, 87:122-130.

38. Nikkhah A: Eating timing an evolutionary manager of postmodern rumen physiology and health: A review. Open Access Anim Physiol 2011, 3:13-19.

39. Sadri $H$, Ghorbani GR, Alikhani M, Babaei M, Nikkhah A: Ground, dry-rolled, and steam-rolled barley grain for midlactation Holstein cows. Anim Feed Sci Technol 2007, 138:195-204.

40. Soltani A, Ghorbani GR, Alikhani M, Samie A, Nikkhah A: Ground versus steam-rolled barley grain for lactating cows: A clarification into conventional beliefs. J Dairy Sci 2009, 92:3299-3305.

41. Emmanuel S, Dunn M, Ametaj BN: Feeding high proportions of barley grain stimulates an inflammatory response in dairy cows. J Dairy Sci 2008, 91:606-614

42. Gozho GN, Plaizier JC, Krause DO, Kennedy AD, Wittenberg KM: Subacute ruminal acidosis induces ruminal lipopolysaccharide endotoxin release and triggers an inflammatory response. J Dairy Sci 2005, 88:1399-1403.

43. Krause KM, Oetzel GR: Understanding and preventing subacute ruminal acidosis in dairy herds: A review. Anim Feed Sci Technol 2006, 126:215-236.

44. Nocek JE, Tamminga S: Site of digestion of starch in the gastrointestinal tract of dairy cows and its effect on milk production. J Dairy Sci 1991, 74:3598-3629

45. Kelly EF, Leaver JD: Lameness in dairy cattle and the type of concentrate given. Anim Prod 1990, 51:221-227.

46. Nocek JE: Bovine acidosis: Implications on laminitis. J Dairy Sci 1997 80:1005-1028. http://www.journalofdairyscience.org/issues/contents? issue_key=S0022-0302(97)X7160-7.

47. González LA, Manteca X, Calsamiglia S, Schwartzkopf-Genswein KS, Ferret A: Ruminal acidosis in feedlot cattle: Interplay between feed ingredients, rumen function and feeding behavior (A review). Anim Feed Sci Technol 2012, 172(1,2):66-79.

48. Nikkhah A, Furedi CJ, Kennedy AD, Crow GH, Plaizier JCP: Effects of feed delivery time on feed intake, rumen fermentation, blood metabolites and productivity of lactating cows. J Dairy Sci 2008, 91:1-12.
49. Bannink A, Gerrits WJJ, France J, Dijkstra J: Variation in rumen fermentation and the rumen wall during the transition period in dairy cows. Anim Feed Sci Technol 2012, 172:80-94.

50. Kleen $J$, Cannizzo $\mathrm{C}$ : Incidence, prevalence and impact of SARA in dairy herds. Anim Feed Sci Technol 2012, 172:4-8.

51. Stone WC: Nutritional approaches to minimize subacute ruminal acidosis and laminitis in dairy cattle. J Dairy Sci 2004, 87:E13-E26.

52. Huntington GB: Starch utilization by ruminants: From basics to the bunk. J Anim Sci 1997, 75:852-867.

53. Herrera-Saldana RE, Huber JT, Poore MH: Dry Matter, crude protein, and starch degradability of five cereal grains. J Dairy Sci 1990, 73:2386-2393.

54. Hall MB, Huntington GB: Nutrient synchrony: Sound in theory, elusive in practice. J Anim Sci 2008, 86:E287-292E.

55. Nikkhah A, Ghorbani GR: Effects of dry and steam processing on in situ ruminal digestion kinetics of barley grain. J Anim Sci 2003, 81:338 (Suppl. 1).

doi:10.1186/2049-1891-3-22

Cite this article as: Nikkhah: Barley grain for ruminants: A global treasure or tragedy. Journal of Animal Science and Biotechnology 2012 3:22.

\section{Submit your next manuscript to BioMed Central and take full advantage of:}

- Convenient online submission

- Thorough peer review

- No space constraints or color figure charges

- Immediate publication on acceptance

- Inclusion in PubMed, CAS, Scopus and Google Scholar

- Research which is freely available for redistribution 